\title{
Az együttmüködés növelésének eszközei a testsúlykontrollban
}

\author{
Czeglédi Edit dr.
}

Semmelweis Egyetem, Általános Orvostudományi Kar, Magatartástudományi Intézet, Budapest

\begin{abstract}
A hosszú távú sikeres testsúlykontroll óriási kihívás elé állítja a súlyfelesleggel élőket és az ooket kezelő szakembereket az elhízásra hajlamosító (obesogen) környezetben. A klinikailag jelentős (5-10\%-os súlycsökkenés) elérése után az elért fogyás megtartása a cél. Ez azonban gyakorlatilag állandóan megköveteli a csábításnak való ellenállást, és tartós erőfeszítéseket igényel az étrendi korlátozás és a fizikai aktivitás tekintetében, amihez jelentôs motivációs bázis szükséges. A viselkedés szempontjából a motiváció annak valószínúsége, hogy a páciens belekezd, folytat vagy kitartóan követ valamilyen, a változást előidéző stratégiát, azaz az elhízás esetében elköteleződik a testsúlykontrolláló egészségmagatartások mellett, illetve felhagy a testsúlykontrollt hátráltató egészségkárosító magatartásokkal. A tanulmány ismerteti a viselkedésváltozás transzteoretikus modelljét, és példákat hoz a motiváció, illetve az együttmúködés növelésének gyakorlati lehetőségeire a viselkedésváltozás minden stádiumában. Mindez hozzájárulhat az alapellátásban és a szakellátásban dolgozó szakemberek munkájához a súlyfelesleggel élő páciensek testsúlycsökkentésének támogatásában.

Orv Hetil. 2019; 160(43): 1687-1697.
\end{abstract}

Kulcsszavak: elhízás, fogyás, súlymegtartás, a viselkedésváltozás transzteoretikus modellje, motiváció

\section{Tools for increasing adherence in weight control}

Long-term successful weight control poses a huge challenge to people who are overweight and treat them in the obesogenic environment. After reaching a clinically significant (5-10\%) weight loss, the goal is to maintain the weight loss achieved. However, this requires virtually constant resistance to temptations and requires sustained effort in terms of dietary restriction and physical activity, which requires a strong motivational base. From the point of view of behavior, motivation is the probability that the patient starts, pursues, or persistently follows a strategy that triggers change, that is, in the case of obesity, is committed to health-related behaviors that support weight management and abandons health risk behaviors that hinders weight control efforts. The present study describes the transtheoretical model of behavioral change and provides examples of practical ways to increase motivation and adherence at all stages of behavioral change. All this can contribute to the work of primary care and outpatient care professionals in supporting weight loss patients with excess weight.

Keywords: obesity, weight loss, weight maintenance, transtheoretical model of behavior change, motivation

Czeglédi E. [Tools for increasing adherence in weight control]. Orv Hetil. 2019; 160(43): 1687-1697.

(Beérkezett: 2019. május 22.; elfogadva: 2019. június 15.)

\section{Rövidítések}

$\mathrm{BMI}=($ body mass index $)$ testtömegindex; HBSC $=($ health behaviour in school-aged children) iskoláskorú gyermekek egészségmagatartása; SMART $=$ (specific, measurable, achievable, realistic, timely) konkrét, mérhető, elérhető, reális, időbeli keretbe illesztett; TTM = (transtheoretical model of behavior change) a viselkedésváltozás transzteoretikus modellje
Az elhízás nagy népegészségügyi jelentőségú, a biopszichoszociális keretmodellben értelmezendő jelenség. Számos krónikus betegség kockázatát jelentősen megnöveli, és maga is krónikus betegségnek tekinthető [1]. Tápláltsági állapota alapján hazánk iskoláskorú (11-18 éves) lakosságának kb. 3\%-a [2], felnőtt lakosságának mindegy egyharmada (32\%-a) [3] él elhízással. A hazai populáció 
további jelentős hányada túlsúllyal bír (iskoláskorúak: $12 \%$ [2], felnőttek: férfiak 40\%, nők 32\% [3]).

A túlsúly és az elhízás kezelésére számos professzionális súlycsökkentő terápia áll rendelkezésre [4], de a fogyókúraipar (valójában inkább hízókúraipar [5]) is szép számmal kínál (gyakorta kifejezetten kétes) megoldási lehetőségeket a súlyfelesleggel élők számára. Mindezen megközelítések sokszínúsége és valós vagy vélt, illetve ígért hatékonysága ellenére hazánk lakosságának BMI-je nőttön-nő [3], ami az elhízás előfordulási gyakoriságának további növekedését vetíti előre. A nyugati társadalom jelenlegi környezete - többek között az urbanizáció, a gépesítés, a tömegközlekedés, a gyakori ülőmunka és a túltáplálkozást promotáló fogyasztói kultúra miatt fellépő pozitív energiamérleg következtében - a súlygyarapodás szempontjából veszélyeztetetté teszi az arra hajlamos személyeket. Ez relatíve lassú folyamat is lehet, érdemes azonban kiemelni, hogy 1 kg hízás is számottevően megnöveli a szív-ér rendszeri betegségek és a diabetes kialakulásának kockázatát [6].

Nagy előfordulási gyakorisága miatt az egészségügyi ellátórendszer bármely szektorában, illetve színterén találkozhatunk súlyfelesleggel élő páciensekkel. Az alapellátásban megjelenő páciensek esetében jól használható lehet a Tsai és Wadden [1] által kidolgozott lépcsőzetes kezelési algoritmus az optimális intervenció megválasztásához a testsúlykontroll támogatásában. Itt érdemes hangsúlyozni, hogy $\mathrm{BMI}<30$ és a komorbid állapotok hiánya esetében az aktuális testtömeg megtartására, azaz a további súlygyarapodás megelózésére érdemes fókuszálni. Komorbid állapotok jelenléte, illetve $\mathrm{BMI} \geq 30$ esetében viszont az első lépésben az 5-10\%-os súlycsökkenést érdemes kitűzni egy hosszabb (például féléves) időkeretben. Az életmódváltásra vonatkozó tanácsadást érdemes kombinálni a kognitív viselkedésterápiás eszköztár alkalmazásával [6-9]. A professzionális súlycsökkentő kezeléstől vonakodó pácienseknek megfontolásra ajánlandók az önsegítés különböző módjai. Mivel az 5-10\%-os súlycsökkenés klinikai értelemben is szignifikánsnak tekinthető, a kitüzött cél teljesítése esetében javasolt az elért fogyás megtartását megcélozni, az egyénre szabott testsúlymegtartási terv kidolgozásával és megvalósításával. A további súlycsökkentést csak egy hosszabb, legalább 4-6 hónapos súlymegtartási fázist követően érdemes megkísérelni. Amennyiben nem sikerül megvalósítani a súlycsökkenést a tanácsadás segítségével, indokolt az intenzívebb kezelési mód (farmakoterápia, étkezéshelyettesítők) bevezetése az 5-10\%-os fogyás elérésének facilitálására. Siker esetében ezúttal is a testsúlymegtartás a következő fázis. Sikertelenség esetében megfontolandó a még intenzívebb kezelés (például bariátriai eljárások) alkalmazása [1]. Az algoritmus előnye, hogy belátható léptékűvé teszi az elérendő súlycsökkenést a szakember és a páciens számára egyaránt, ugyanakkor útmutatást is ad az alapellátás különböző szektoraiban dolgozó szakembereknek, hogy melyik kezelési módot milyen esetben érdemes megfontolni, illetve kezdeményezni.
Hangsúlyozandó, hogy a súlyfelesleggel bírók, és különösen az elhízással élők esetében igen erôs a társadalmi stigma, a megbélyegzettség, ami az egészségügyi ellátórendszerben is gyakorta megtapasztalható $[10,11]$. Érdemes ezért a szakembereknek önvizsgálatot tartaniuk, hogy vajon hogyan gondolkodnak az elhízás okairól, milyen attitûddel viseltetnek az elhízással élő páciensek irányában, és ez hogyan nyilvánul meg a viselkedésükben a mindennapi munkájuk során. A saját attitűdök megismerését és tudatosulását segíthetik az alábbi kérdések [11]: 1) Vajon pusztán a testtömege alapján vannak-e elöfeltételezéseim egy egyén jelleméröl, intelligenciájáról, szakmai sikerességéről, egészségi állapotáról vagy életmódjáról? 2) Bármely testalkatú emberrel ugyanolyan komfortosan dolgozom-e együtt? 3) Érzékeny vagyok-e az elhizással élo" egyének szükségleteire és aggodalmaira? További kérdés lehet, hogy „Vajon hogy érzik magukat a súlyfelesleggel él” pácienseim, amikor elhagyják a rendelömet?”

$\mathrm{Az}$ állapotukért a pácienseket hibáztató gondolkodásmód szemléletformálást igényel, a megalázó bánásmód pedig feltétlenül kerülendő, mert visszatarthatja a pácienseket a szűrővizsgálatokon való megjelenéstől és az észlelt egészségi problémák időben történő jelzésétől, továbbá önértékelésükre is negatívan hathat, emellett a megaláztatás következtében olyan magatartások jelenhetnek meg náluk (például falásroham, érzelmi evés), amelyek hozzájárulnak a súlyprobléma fennmaradásához, illetve fokozódásához [12]. Bármennyire nehéz és kihívást jelentő feladat is a súlycsökkenés elérése, és frusztráló a siker elmaradása, nagyon fontos, hogy a szakemberek kellő érzékenységgel, empátiával és türelemmel közeledjenek a súlyfelesleggel élő pácienseik felé (is). Számos szakkönyvben a terápiás protokoll mellett konkrét példamondatokat, párbeszédeket láthatunk, amelyek szemléltetik azt a kommunikációs stílust és hozzáállást, amely optimálisan szolgálja a megfelelő rapportépítést, a páciensek bevonását a kezelésbe és az együttmúködés növelését $[9,13,14]$. A szenzitív bánásmód egyik eleme a szóhasználat. Mivel egyes szavak kifejezetten megbélyegzők és hibáztatók (például kövér, hájas), míg mások semlegesebbek (például súlyprobléma, súly) [15], érdemes megtudakolni a pácienstől, hogy milyen kifejezést szeretne használni a testtömegéról folytatott beszélgetések során. Ugyancsak érdemes törekedni a páciensbarát rendelő kialakítására, amely a tápláltsági állapottól függetlenül kényelmes, és olyan orvostechnikai eszközökkel bír, amely minden páciens számára lehetővé teszi a megfelelő kivizsgálást [11].

\section{A viselkedésváltozás transzteoretikus modellje}

A fogyás és az elért testtömeg tartós megtartása életmód-változtatást igényel, méghozzá igen széles körben. Nemcsak a meglévő, táplálkozásra és fizikai aktivásra vonatkozó magatartások és szokások megváltoztatására, leépítésére vagy újak kialakítására van szükség, hanem 
intraperszonális (például gondolkodásmód, érzelemszabályozási módok), interperszonális (például önérvényesítés) és mikrokörnyezeti változtatásokra is. Ráadásul élethossziglan. E változások véghezvitele nagy energiabefektetést igényel a páciensektől, emellett egyidejüleg vagy időben egymáshoz közel történnek, ugyanakkor a változásra való készenlét nem feltétlenül azonos stádiumából indulnak. Éppen ezért lényeges a változás stádiumát felmérni és számításba venni az intervenciók tervezése során. A viselkedésváltozásnak számos pszichológiai modellje létezik (ld. áttekintésként [16]). A viselkedésváltozás transzteoretikus modelljének (TTM) [17, 18] ismerete és alapulvétele különösen hasznos a gyakorlati munka szempontjából.

A modell alaptétele, hogy a viselkedésváltozás nem egyszeri esemény, amely egyik napról a másikra történik meg, hanem folyamat, amely időben hosszan elnyúlhat, és szakaszok meghatározott sorozatán megy keresztül. E szakaszok megkülönböztető pszichológiai jellegzetességekkel bírnak. A megbotlás és a visszaesés a változás folyamatának jellemző, gyakorlatilag normatívnak tekinthető aspektusa [17, 18]. Mindezt jól szemlélteti a változás folyamatát spirálszerúen megjelenítő 1 ábra.

A TTM-nek az elhízás kezelésében való alkalmazási lehetőségeiről több helyütt is olvashatunk [19, 20]. Az egyes szakaszok fóbb jellemzőit és a szakember jellemző feladatait [21] az 1. táblázat foglalja össze [18, 21].

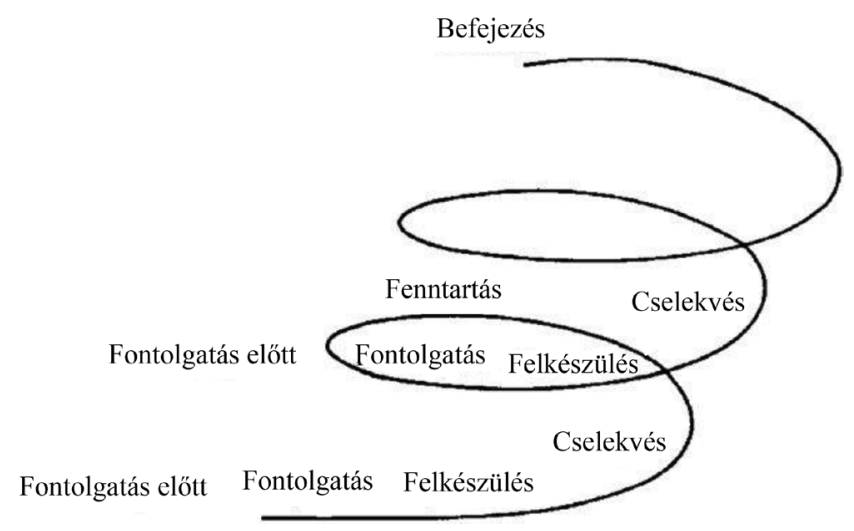

1. ábra | A változás folyamatának spirális modellje [17, p. 1104]

Megjegyzendő, hogy a testsúlykontroll az elhízásra hajlamosító (obesogen) környezetben gyakorlatilag állandóan megköveteli a csábításnak való ellenállást, és tartós erőfeszítéseket igényel az étrendi korlátozás és a fizikai aktivitás tekintetében egyaránt. Kristal és mtsai [22] érvelése szerint az étrendi változás esetében a cselekvés és a fenntartás stádiumát az egészséges ételválasztással kapcsolatos kognitív és viselkedéses éberség kialakulásának és fennmaradásának keretében célszerű értelmezni. A cselekvés stádiumában a személy megpróbál elsajátítani számos új étrendi magatartást (például a zöldség- és

1. táblázat |A viselkedésváltozás stádiumai és a szakember feladata

\begin{tabular}{|c|c|c|}
\hline A változás stádiuma & A páciens jellemzői [18] & A szakember feladata [21] \\
\hline A fontolgatás elôtti fázis & $\begin{array}{l}\text { Nem áll szándékában a testsúlykontroll elkezdése a belátható jövőben } \\
\text { (fél éven belül). } \\
\text { Nem gondolja problematikusnak a súlyfeleslegét. (Ennek hátterében } \\
\text { például az ismeretek hiányossága, illetve a testsúlykontroll korábbi } \\
\text { kudarca állhat.) } \\
\text { Nem áll készen a változásra. }\end{array}$ & $\begin{array}{l}\text { Kétség keltése: a páciens kockázatészlelésé- } \\
\text { nek és az aktuális viselkedés problémás } \\
\text { volta észlelésének növelése. }\end{array}$ \\
\hline A fontolgatás fázisa & $\begin{array}{l}\text { Nem törekedik ugyan aktívan a testsúlykontrollra, de komolyan } \\
\text { fontolgatja ennek elkezdését az elkövetkező hat hónapon belül. } \\
\text { A változással kapcsolatban ambivalens. } \\
\text { Nem áll készen a változásra. }\end{array}$ & $\begin{array}{l}\text { Az egyensúly felbillentése: a változás } \\
\text { értelme, a nem változás kockázatai. } \\
\text { A páciens énhatékonyságának erősítése az } \\
\text { aktuális viselkedés megváltoztatása kapcsán. }\end{array}$ \\
\hline A felkészülés fázisa & $\begin{array}{l}\text { Szándékában áll a testsúlykontroll elkezdése a közeljövőben, } \\
\text { méghozzá az elkövetkezô hónapban. } \\
\text { Már megtett kisebb-nagyobb lépéseket a cél érdekében, illetve } \\
\text { terveket kovácsol. } \\
\text { Szakemberekhez fordul tanácsért, segítségért. } \\
\text { Készen áll a változásra. }\end{array}$ & $\begin{array}{l}\text { Segíteni a páciensnek meghatározni a } \\
\text { legjobb cselekvési módokat a változásra } \\
\text { való törekvés során. }\end{array}$ \\
\hline A cselekvés fázisa & $\begin{array}{l}\text { Egyértelmú, konkrét életmódbeli változtatásokkal aktívan törekszik } \\
\text { a testsúlykontrollra, és sikert ért el, mindez azonban hat hónapnál } \\
\text { kevesebb ideje zajlik. }\end{array}$ & $\begin{array}{l}\text { Segíteni a páciensnek a változás } \\
\text { felé történő lépések megtételében } \\
\text { (pl. edukáció, készségfejlesztés). }\end{array}$ \\
\hline A fenntartás fázisa & $\begin{array}{l}\text { Az elért súlycsökkenést legalább hat hónapja sikeresen megtartja. } \\
\text { Aktívan dolgozik a visszaesés megelőzésén. } \\
\text { Egyre nő az önbizalma arra vonatkozóan, hogy képes fenntartani } \\
\text { az eddig történt változtatásokat. }\end{array}$ & $\begin{array}{l}\text { Segíteni a páciensnek azonosítani } \\
\text { és gyakorolni a megbotlást, illetve } \\
\text { a visszaesést megelőző stratégiákat } \\
\text { (pl. cselekvési tervek kidolgozása). }\end{array}$ \\
\hline Visszaesés & $\begin{array}{l}\text { Visszalépés a változás folyamatának bármely korábbi stádiumába. } \\
\text { Ennek kapcsán változatos pszichológiai reakciók léphetnek fel, mint } \\
\text { például önvádlás, kétségbeesés, katasztrofizálás, bagatellizálás, apátia. }\end{array}$ & $\begin{array}{l}\text { Segíteni a páciensnek a fontolgatás, } \\
\text { a felkészülés és a cselekvés folyamatainak } \\
\text { megújításában anélkül, hogy a páciens } \\
\text { nagyon elkeseredne a visszaesés miatt, vagy } \\
\text { benne ragadna. }\end{array}$ \\
\hline
\end{tabular}


gyümölcsfogyasztás növelése, a cukrozott üdítőitalok fogyasztásának korlátozása, a rendszeres étkezés bevezetése, a napi legfeljebb 5 étkezés tartása). A konkrét viselkedések tekintetében ugyanazon személy egyazon időpontban a változás különböző stádiumaiban állhat. A fenntartás fázisában lévő személy viszont már elegendő új viselkedést sajátított el ahhoz, hogy elérje a kívánt célt, azonban egy új magatartás (például egy korábban nem ismert, zsírszegény fözéstechnikai eljárás) bevezetése esetében ennek megszilárdulása is végighalad a viselkedésváltozás teljes folyamatán. Ebben a kontextusban pedig a cselekvés és a fenntartás közötti ingadozás pozitívan értékelendő, és nem tekintendő relapsusnak. Mindez közelebb visz bennünket a fenntartás stádiuma jellegzetességeinek megértéséhez a testsúlykontrollal kapcsolatos viselkedésváltozás kontextusában.

A TTM általános leírásaiban létezik egy 6. szakasz, a befejezés stádiuma is [17-18]. Ebben a szakaszban az egyének már nem esnek kísértésbe, és az énhatékonyságuk 100\%-os. Bármilyen hangulati állapotban vannak is, megküzdési módként egészen biztosan nem térnek viszsza a korábbi egészségkárosító szokásukhoz. Az előzőekben írottakkal összhangban a befejezés stádiuma kevéssé tünik alkalmazhatónak a testsúlymenedzselésre, hiszen a jelentôs súlyfelesleggel élők a legritkább esetben érik el az egészségesnek tartott testtömegtartományt. Emellett bármennyit fogynak is, a testsúly megtartása gyakorlatilag életre szóló feladat. Prochaska és Prochaska [19] maguk is belátják, hogy az olyan területeken, mint amilyen például a fizikai aktivitás vagy a testsúlykontroll, a reális cél a fenntartás stádiumának élethosszig történó megmaradása.

A viselkedésváltozás stádiumának felmérése történhet magára a testsúlykontrollra (2. táblázat), illetve az azt szolgáló különféle viselkedésekre vonatkozóan is [22, 23]. Ez azért lényeges, mert ezáltal lehetôség nyílik a változást optimálisan szolgáló intervenciók kiválasztására és megvalósítására. Egy egyszerü példával élve, ha a páciens a felkészülés fázisában van, akkor már nincs szükség a változásra való motiválásra. Helyette megkezdődhet a cselekvésorientált intervenció, például a viselkedésváltozásra vonatkozó konkrét tanácsadás, illetve a változás gyakorlati akadályainak feltérképezése és elhárítása. Ezzel szemben ha a páciens a fontolgatás előtti fázisban van, akkor teljesen felesleges az életmódváltásra buzdítani. Ehelyett a problémaészlelés növelésére szükséges fókuszálni, hogy elmozduljon a fontolgatás fázisa felé; majd a változással kapcsolatos ambivalenciájának feltérképezésére és feloldására, hogy elköteleződhessen a változás mellett, és megkezdje az arra való előkészületeket. Ez utóbbiakban a motivációs interjú $[21,24,25]$ megközelítésének alkalmazása különösen gyümölcsöző lehet, amely az alapellátásban is megvalósítható [26], a szakellátásban dolgozók (például obezitológusok, diabetológusok, dietetikusok) esetében pedig különösen ajánlott.

\section{A motiváció formái és jelentősége a testsúlykontroll szempontjából}

A súlycsökkenésre irányuló törekvések hátterében meghúzódó motiváció mennyiségi és minőségi szempontból egyaránt értelmezhető [27]. A mennyiségi aspektus jól megragadható Miller és Rollnick [21] definíciójában. E szerint „A motiváció a változásra való készenlét vagy hajlandóság állapota, amely helyzetről helyzetre változik. Ez az az állapot, amelyre befolyást gyakorolhatunk" [21, p. 14]. A viselkedés szempontjából a motiváció annak a valószínúsége, hogy a páciens elkezd, folytat vagy kitartóan követ valamilyen, változást előidéző stratégiát [21, p. 19]. A fentiekből látható, hogy a motiváció nem egy általános vonás (hiánya pedig nem a jellemgyengeség jele), hanem a kontextustól függ.

2 táblázat | A viselkedésváltozás stádiumának felmérése - testsúlykontroll [23]

Kérjük, olvassa el az alábbi kérdéseket, és karikázza be az Önre leginkább jellemző választ!

1. Törekedett-e az elmúlt hónapban arra, hogy csökkentse a testsúlyát? Igen/Nem

2. Tett-e az elmúlt hónapban lépéseket azért, hogy megelőzze testsúlyának növekedését? Igen/Nem

3. Komolyan gondolkodik-e azon, hogy csökkentse a testsúlyát az Ön által kitűzött mértékben az elkövetkező 6 hónapban? Igen/Nem

4. Komolyan gondolkodik-e azon, hogy elkezdi csökkenteni a testsúlyát az elkövetkezendő egy hónapban? Igen/Nem

5. Megtartotta-e az Ön számára kívánatosnak vélt testsúlyt több mint 6 hónapig? Igen/Nem

Pontozás:

\begin{tabular}{|c|c|c|c|c|c|}
\hline \multirow[t]{2}{*}{ A változás stádiuma } & \multicolumn{5}{|c|}{ Kérdés } \\
\hline & 1. & 2. & 3. & 4. & 5. \\
\hline Fontolgatás előtti & Nem & Nem & Nem & & \\
\hline Fontolgatás & Nem & Nem & Igen & Nem & \\
\hline Felkészülés & Nem & Nem & Igen & Igen & \\
\hline Cselekvés & \multicolumn{2}{|c|}{ Igen az 1 . vagy a 2. kérdésre } & & & $\mathrm{Nem}$ \\
\hline Fenntartás & \multicolumn{2}{|c|}{ Igen az 1 . vagy a 2 . kérdésre } & & & Igen \\
\hline
\end{tabular}


A minőségi aspektus arra vonatkozik, hogy mit szeretne elérni a páciens a súlycsökkenés segítségével [27]. Ezeket a célokat Cooper és mtsai [13] kifejezésével elsődleges céloknak nevezzük. E célok igen változatosak abban a tekintetben, hogy mennyire kapcsolódnak valójában a fogyáshoz (akár egyáltalán nem, erre példa a párkapcsolat javulása), ugyanakkor azonosításuk több okból is lényeges. Egyfelől alapul szolgálnak a motiváció mennyiségének, illetve annak növelésének; továbbá segítenek a szakembernek megtalálni azokat a testsúlykontrollt szolgáló magatartásokat, amelyek intrinszik módon (belsőleg) motiváltak, önmagukban örömteliek, és amelyek révén az egyén kielégítheti három pszichológiai alapszükségletét, nevezetesen az autonómia, a kompetencia és a kapcsolódás szükségletét [27]. Másfelől egyes elsődleges célok, amelyek extrinszik módon (külsőleg) motivált viselkedéseket eredményeznek, ráadásul nem vagy csak érintőlegesen kapcsolódnak a súlycsökkenéshez (például a munkahelyváltás, egy adott személy roszszallásának elkerülése), akadályát képezhetik a testsúlykontrollt szolgáló egészségmagatartások hosszú távú folytatásának, valamint a kezelés során elért fogyás elfogadásának, ezáltal növelik a visszahízás veszélyét $[13,27]$.

\section{A változás folyamatát segítő technikák a mindennapi gyakorlatban}

A változás folyamata számos stratégia tudatos alkalmazásával facilitálható a szakember részéről. A következőkben erre mutatunk be példákat (a teljesség igénye nélkül) a testsúlykontroll kontextusában.

Az elhízás gyakorlatilag valamennyi szervrendszer esetében kockázatot jelent a tünetek, illetve betegségek megjelenésére [28]. Bármely szakágban dolgozunk tehát, világosan láthatjuk, hogy a páciens tápláltsági állapota mely panaszok megjelenésével függhet össze. Nem biztos azonban, hogy maga a páciens is átlátja ezt az öszszefüggést, éppen ezért érdemes ezt felmérni. Ez történhet egy egyszerü kérdéssel, úgymint „Mit gondol, mi állhat a ... (itt megnevezzük az adott problémát, tünetet) hátterében?"Ha a páciens szemlátomást nem látja a súlyprobléma lényegi szerepét (illetve a fontolgatás előtti fázisban van a testsúlykontroll szempontjából), a problémaészlelés növelése érdekében kulcsfontosságú, hogy rávilágítsunk a súlyfeleslege és például az ízületi fájdalmai, a menstruációs ciklusának rendszertelensége, a magas vérnyomása vagy a magas éhomi vércukorszintje közötti kapcsolatra. Első lépésben ez történhet például az alábbi kérdés formájában: „Mit gondol, összefügghet-e a súlyfeleslege ezzel a problémával?” Nemleges válasz esetében érdemes engedélyt kérni a pácienstől arra nézve, hogy megoszthassuk vele a vonatkozó ismereteinket [9].

A motiváció mennyiségi aspektusa egyszerü kérdésekkel feltérképezhető az ún. vonalzótechnika alkalmazásával $[24,26]$. Erre példa annak megtudakolása, hogy egy skálán az egyáltalán nem fontos (0) és teljes mértékben fontos (10) végpontok között mennyire fontos az illetőnek, hogy csökkentse a testtömegét. A páciens várhatóan a 0-nál nagyobb értéket fog megjelölni. Ezen a ponton lehetőségünk nyílik a motiváció növelésére oly módon, hogy rákérdezünk arra, hogy miért az adott értéket adta meg, miért nem kevesebbet, mondjuk egyet vagy akár a nullát. A kérdés megválaszolása során a páciens saját maga kezd el érvelni a változás szükségessége mellett (ez a motivációs interjú megközelítésének egyik kulcsmomentuma [21]), felsorakoztatva például a súlyfeleslege által megtapasztalt hátrányokat vagy a fogyás előnyeit (egyben a motiváció minőségi aspektusaiba engedve betekintést), ami önmagában fokozza a változásra való készenlét erősödését (azaz a motiváció mennyiségének növekedését). További lehetőség annak feltárása, hogy mire lenne szüksége a páciensnek, illetve minek kellene történnie ahhoz, hogy az érték magasabb legyen.

A fontolgatás fázisában a változással kapcsolatos ambivalencia feltárására kiválóan alkalmazható a költség-haszon-elemzés vagy döntési egyensúly [21, 24, 26]. Ennek során arra kérjük a pácienst, hogy szedje csokorba (akár egyénileg otthon), hogy mi lenne az előnye annak, ha sikerülne elérnie a kívánt súlycsökkenést, ugyanakkor milyen nehézségekkel, illetve hátrányokkal járnának a súlycsökkentési erőfeszítései. A nem fogyás, illetve további hízás vélt hátrányai mellett annak előnyeit is szükséges górcső alá venni. Egy általam vezetett csoportban az egyik férfi csoporttag ez utóbbi kapcsán értetlenül (és szinte felháborodottan) jelezte vissza, hogy hogy kérdezhetek ilyen ostobaságot, hogyan is lehetne bármi előnye a súlyfeleslegüknek. Ez a példa is aláhúzza annak fontosságát, hogy szükséges tudatosítani a páciensekben súlyfeleslegük elónyeit, pozitív aspektusait is, mert ezek is lényegi akadályát képezhetik a változásnak. Ha a páciens nehezen boldogulna a táblázat kitöltésével, számos segítő kérdéssel támogathatjuk a súlycsökkentéssel kapcsolatos ambivalencia feltérképezését. Például: „Miben korlátozza a súlyfeleslege?”, „Mitől tart/fél a súlyfeleslegével kapcsolatban?”, „Miben volt más az élete, amikor 10 kg-mal kevesebb volt a testtömege?” A 3. táblázatban a klinikai munkám során gyújtött szempontokból mutatok be példákat. A felsorolásból látható, hogy mind a súlycsökkenés, mint pedig annak hiánya jelentős előnnyel és hátránnyal bírhat a súlyfelesleggel élők számára. A cellákban gyakoriak az egészséggel és a külső megjelenéssel kapcsolatos szempontok, azonban számos olyan aggodalom is fellelhető, amelyre nem feltétlenül gondolnánk a hétköznapi munka során (például a „védoofal” elveszítése, a „valódi” problémákkal való szembesülés, a szexuális közeledés), ugyanakkor segítenek rávilágítani a súlyprobléma komplex hátterére és meghaladni a pácienseket az „akaratgyengeségük” miatt elmarasztaló szemléletet. $\mathrm{Az}$ is látható, hogy az előnyök és a hátrányok különböző súllyal esnek a latba: nyomós és kevésbé nyomós érvek és ellenérvek egyaránt felfedezhetők. Az elkészült táblázat megbeszélése során érdemes a szókratészi kérdezéshez [21] folyamodni, azaz olyan kérdéseket tenni fel, ame- 


\begin{tabular}{|c|c|c|}
\hline & Előnyök & Hátrányok \\
\hline Fogyás & $\begin{array}{l}\text { - Új lehetőségek nyílnak meg előttem } \\
\text { - Csökken a betegségek kockázata, javul az egészségem } \\
\text { - Könnyebb mozgás } \\
\text { - Csökken a kiszolgáltatottságom } \\
\text { - Nő az önbecsülésem és az önbizalmam } \\
\text { - Tehetségesebbnek, okosabbnak tartanak, ha soványabb } \\
\text { vagyok } \\
\text { - Kevésbé leszek hátrányos helyzetben } \\
\text { - Nagyobb lesz az esély a munkahelyi elóléptetésre } \\
\text { - Javul a szexuális életem } \\
\text { - Csinosabban öltözködhetek } \\
\text { - Csökken a horkolás és az alvási apnoe } \\
\text { - Csökkennek a mozgásszervi fájdalmaim } \\
\text { - Javul az életminőségem } \\
\text { - Hosszabb életkort élhetek meg } \\
\text { - Javul a testhigiéniám } \\
\text { - Példát mutathatok a gyermekeimnek, családomnak } \\
\text { - Javul a közérzetem } \\
\text { - Növekszik a fizikai aktivitásom } \\
\text { - Nő a pozitív visszajelzések száma } \\
\text { - Mintát/példát nyújtok szeretteimnek, környezetemnek }\end{array}$ & $\begin{array}{l}\text { - Fonnyadt, striás bőr, narancsbőr, lógó bőr, lógó has } \\
\text { - Sok kiadás új ruhákat venni } \\
\text { - Más étrendet igényel, nehéz lehet az átállás } \\
\text { - Többet várnak tőlem } \\
\text { - Lemondásokat követel } \\
\text { - Félelem a visszahízástól } \\
\text { - Az új lehetőségek megnyílása veszélyezteti a stabilitásomat } \\
\text { - Elveszítem a védőfalamat } \\
\text { - Nagyobb elvárásokat támasztanak az irányomban } \\
\text { - Kritikák a környezetemtooll } \\
\text { - Fáradékonyság } \\
\text { - Fázósabbá válok } \\
\text { - Félelem a betegségektől } \\
\text { - Szembesülök azzal, hogy nem is a súly az igazi probléma } \\
\text { - Szembesülök azzal, hogy bizonyos problémáimnak nem is } \\
\text { a túlsúly az igazi oka } \\
\text { - Az engem kínálgatók megsértődnek a visszautasítástól } \\
\text { - Mások csak a fogyókúráról beszélnek velem, mintha egy } \\
\text { lennék a fogyókúrával } \\
\text { - Félelem attól, hogy túllövök a célon, és túlságosan lefogyok }\end{array}$ \\
\hline $\begin{array}{l}\text { Nem fogyás / } \\
\text { hízás }\end{array}$ & $\begin{array}{l}\text { - Bármikor, bármit, bármennyit ehetek } \\
\text { - Nem frusztrálódom a célom kitűzése és nem teljesítése miatt } \\
\text { - Szabadság, nincsenek béklyók } \\
\text { - Lázadok } \\
\text { - Felmentést kapok a kötelezettségeim alól } \\
\text { - Megmarad a védőfalam } \\
\text { - Jutalmazhatom magam étellel } \\
\text { - Evéssel nyugtathatom meg magam, így el tudok aludni } \\
\text { - Nem kell görcsölni azon, hogy mit és mennyit ehetek } \\
\text { - Kényelmes } \\
\text { - Védőburokban maradhatok } \\
\text { - Nincsenek extra elvárások velem szemben } \\
\text { - A hájrétegem megvéd a férfiaktól } \\
\text { - Nem kell felvállalnom egy élethosszig tartó projektet }\end{array}$ & $\begin{array}{l}\text { - Megnő a betegségek kialakulásának kockázata } \\
\text { - Romlik az egészségem } \\
\text { - Rossz közérzet } \\
\text { - Korlátozódnak az életlehetóségeim } \\
\text { - Korlátozott a mozgásszabadságom } \\
\text { - Önbizalomhiány } \\
\text { - Önutálat, undor } \\
\text { - Megromlanak a kapcsolataim } \\
\text { - A környezetem aggódik értem/sajnálkozik rajtam/piszkál } \\
\text { - Fáradékony leszek } \\
\text { - Korlátozottak a ruhavásárlási lehetőségeim } \\
\text { - Megfosztom magam bizonyos élményektől (például } \\
\text { csúszdapark) } \\
\text { - Rosszabb a társadalmi megítélésem } \\
\text { - Másokkal szemben hátránnyal indulok }\end{array}$ \\
\hline
\end{tabular}

lyek nem konfrontatívak, ugyanakkor a megválaszolásuk gondolkodást igényel, rávilágít a logikai hibákra, elősegíti a probléma jobb megértését, hozzásegítve a válaszadót a saját megoldásai megtalálásához. Például: „Gondolkodott-e már igy a testsúlyáról?”, „Hogy látja most a testsúlyát?”, „Mit gondol, hogy alakul az élete 10 év múlva?”, „Melyek a hosszú távú céljai? Mit gondol, mennyiben tudnak ezek megvalósulni akkor, ha nem változik a testtömege, vagy akár tovább gyarapodik a testsúlya?” A súlyfelesleg fennmaradását támogató pozitív incentívek tisztázása után a szakember feladata ezek csökkentése, aláásása és ellensúlyozása ezek kívánatosságának csökkentése érdekében [21]. Mindezek segítségével a páciensek általában rá szoktak ébredni arra, hogy bár rövid távon a súlyfeleslegük előnyös lehet számukra, hosszú távon azonban jelentős akadályát képezik vágyaik, életcéljaik megvalósításának. Ahogy azzal is szembesülnek, hogy bár a testsúlykontroll rövid távon kifejezetten megterhelő és nehéz lehet, hosszú távon azonban megéri a befektetett erőfeszítés. Éppen ezért ez a technika rendkívül jól alkalmazható arra, hogy elősegítsük a változás mellett szóló érvek erősödését és a változás ellen szóló érvek gyengülését, ami viszont támogatja a változással kapcsolatos ambivalencia feloldását és a változás iránti elköteleződést.

Előfordulhat, hogy a páciens készen áll a változásra (a felkészülés szakasza), szeretne is fogyni, de nem tudja, hogyan tegye ezt. Ilyenkor lehet nagy szerepe a jól időzített és világos tanács adásának. Miller és Rollnick [21] a hatékony tanács három kulcselemének az alábbiakat tartják: 1) Világosan, egyértelmúen meghatározza a problémát vagy a kockázatot. 2) Megmagyarázza, hogy miért fontos a változás. 3) Konkrét változtatást javasol. Az utóbbi azért különösen fontos, mert a páciensek gyakorta általános tanácsokat kapnak a szakemberektől, úgymint „Változtasson életmódot!”, „Fogyjon le!”, „Mozogjon többet!’ Ezeket azonban igen nehéz tettekre váltani. Éppen ezért érdemes konkrét célokat kitűzni a testtömeg, az evés és a fizikai aktivitás terén egyaránt, majd ezeket átfordítani viselkedéses megfelelőkbe, pontosan meghatározva, hogy hol, mikor és hogyan hajtsák végre a cél elérését szolgáló viselkedéseket. A célok rövid és hosszú távúak egyaránt lehetnek [7]. A testtömegcsökkenés te- 
kintetében konkrét cél lehet a kiindulási testtömeg 10\%ának leadása fél év alatt, heti 0,5-1 kg-os ütemezéssel. Az „Egyen kevesebbet!” felszólítás helyett kerüljön kiszámításra a napi 500 kcal energiadeficitet eredményező kalóriabevitel. Amennyiben az aktuális fogyasztáshoz képest radikális kalóriakorlátozásra lenne szükség, érdemes ezt is kis lépésekre lebontva, heti $300 \mathrm{kcal}-\mathrm{lal}$ csökkentve elérni az ajánlott napi energiabevitelt [29]. Az „Egyen több gyümölcsöt!” tanács helyettesítendő például az alábbival: „Egyen naponta legalább $0,5 \mathrm{~kg}$ gyümölcsöt és/vagy zöldséget.” A konkrét viselkedés szintjén ez például az alábbi formában javasolható: „Minden étkezés során fogyasszon gyümölcsöt vagy zöldséget.” A fizikai aktivitás növelése kapcsán pedig például a napi hatezer lépés megtétele javasolható kezdésnek (és a lépésszámot 500-asával növelve eljutni a napi 10000 lépéshez). Bármi legyen is a cél, fontos, hogy a pácienssel közösen, vele egyetértésben kerüljön megfogalmazásra. A célkitűzésnél javasolt a SMART-célállítás [30] követése, azaz konkrét, mérhető, elérhető, reális és időbeli keretbe helyezett célok kerüljenek megfogalmazásra. Az étkezésre vonatkozó célok elérése során hasznos eszköz lehet például az (ugyancsak a viselkedésterápiából ismert) viselkedéses helyettesítés technikája, amelynek segítségével a magasabb energiatartalmú ételek kiválthatók alacsonyabb energiatartalmú alternatívákkal. Például cukor helyett édesítőszer használata; olajban sütés helyett párolás vagy zacskóban sütés; fehér lisztből készült pékáru helyett teljes kiőrlésű gabonából készült pékáruk fogyasztása. Ennek azért van kiemelt jelentősége, mert relatíve kisebb változtatások, amelyeket különösebb nehézség, illetve lemondás nélkül be lehet illeszteni a mindennapi életbe, a hatásuk azonban összeadódik, ami a kalóriabevitel jelentős csökkenését eredményezi, ezáltal elősegíti a súlycsökkenést, és növeli az önbizalom, illetve az énhatékonyság érzését. Ez utóbbi a személy saját képességeibe vetett bizalmát jelenti, hogy el tudja érni a kívánt célt, és az arra vonatkozó hitet, hogy képes befolyásolni a körülötte zajló eseményeket. A testsúlykontrollal kapcsolatos énhatékonyság-érzés erősítése a súlyfelesleggel bíró páciensek esetében kiemelt szereppel bír, mert végső soron nagyobb fokú kezelési együttműködést és a súlycsökkenést, illetve a hosszú távú súlymegtartást elősegítő magatartások folytatását eredményezi [31]. A célállítás és az annak teljesítését elősegítő viselkedések megtervezése és megvalósítása a különböző viselkedésterápiás technikák alkalmazásával a cselekvés és a fenntartás szakaszában egyaránt szükséges.

Bármennyire motivált is azonban a páciens a testsúlykontrollra, a viselkedésváltozás akadályokba ütközhet. Az akadályok a változás folyamatának bármely stádiumában megjelenhetnek, és igen sokfélék lehetnek. Lehetnek például előre láthatók vagy előre nem láthatók; kézzelfoghatók vagy inkább attitűdbeliek; intraperszonálisak, interperszonálisak vagy akár kontextushoz kötöttek. Érdemes ezeket feltérképezni és elhárítani [21]. Néhány példát kiemelve: ha az egyes ételcsoportok tápértékére vonatkozóan hiányos ismeretekkel bír a páciens, akkor ez kiváló terep az edukációnak és a páciens segédanyagokkal történő ellátásának. A súlyfelesleggel élők körében gyakori jelenség az impulzív, gyors, öntudatlan evés, ami könnyen vezethet túlzott kalóriabevitelhez. Ilyen esetben például a jelentudatos evés [32] gyakorlásának támogatása segíthet. Ha pedig a páciensnek a súlyfelesleget fenntartó szokásai vannak (például tv-nézés közbeni nassolás), akkor e szokások kiiktatása a cél. Ez azért különösen jelentős, mert ha az új, adaptív viselkedés végrehajtására vonatkozó szándék és maga a cselekvés közé beékelődik egy szokás, akkor a szándék hatása az adaptív viselkedésre a szokás erősségével arányosan csökken [29]. E szokások leépítésére számos viselkedésterápiás stratégia (például ingerkontroll, viselkedéses helyettesítés) bevethető. A személyen belüli további akadályra példa az emocionális evés, amely a kellemetlen, illetve nehezen tolerálható érzések, érzelmek (például fáradtság, unalom, bánat, feszültség) csökkentésére irányuló, maladaptív megküzdési stratégiának tekinthető. Ebben az esetben javasolt lehet a problémamegoldás technikájának alkalmazása az alternatív feszültséglevezető módok megtalálása érdekében. A problémamegoldás stratégiája jól használható lehet más intraperszonális (például a testmozgástól való vonakodás), illetve az egyén életviteléből következő akadályok leküzdésére is (például a gyermekfelügyelet megoldása a testgyakorlás idejére; a rendszeres étkezés bevezetésének kieszközlése; a családtagok által is elfogadható, mégis csökkentett energiatartalmú menüsorok megtervezése). Az interperszonális akadályokra példa az ismerősök általi, étellel való túlzott kínálgatás; vagy a testsúlykontroll családtagok általi megnehezítése például együtt nem múködéssel vagy elbátortalanító megjegyzésekkel. Ezekben az esetekben az önérvényesítés (asszertív kommunikáció) készségének fejlesztése segíthet az akadályok leküzdésében. A hazánkban is elérhető Williams ÉletKészségek ${ }^{\circledR}$ Stresszkezelő és Pszichoszociális Készségfejlesztő Tréning számos olyan technikát tartalmaz, amely segít a testsúlycsökkentés akadályainak leküzdésében. A program egészségügyben dolgozó szakemberek és laikusok számára egyaránt elérhető (az utóbbiak esetében olykor térítésmentesen is), emellett önsegítő formában is kapható [33].

Miller és Rollnick [21] hangsúlyozzák, hogy az emberek nem szeretik, ha megmondják nekik, hogy mit tegyenek, és ellenállás várható, ha a személyek úgy észlelik, hogy a szabadságuk veszélyeztetett vagy korlátozott. Ez összhangban áll a fent említett alapvető pszichológiai szükségletek közül az autonómia szükségletével [27]. Éppen ezért a szakembernek érdemes választási lehetőségeket nyújtani a viselkedésváltozás folyamán mindvégig, annak bármely stádiumában, és segíteni abban, hogy a páciens érezze a személyes választása szabadságát (és valójában a felelősségét). A választási lehetőség több szinten is megjelenhet és sokféle lehet, a kezelési céloktól kezdve a megvalósítás módjáig, priorizálásáig és ütemezéséig. E megközelítés azért különösen hasznos, mert az 
alternatívák közötti választási lehetőség nyújtása csökkenti az ellenállást és a kezelésből való lemorzsolódást, emellett javíthatja a motivációt, az együttmúködést és a kezelési kimenetet egyaránt [21].

A súlyfelesleg és a testsúlykontroll rendkívül szenzitív téma, ezért különösen fontos, hogy a szakemberek kellő érzékenységgel, együttérzéssel és empátiával viseltessenek súlytöbblettel élő pácienseik irányában $[11,14]$. Az empátia kedvez a páciens motivációjának, alacsonyabb ellenállással és nagyobb mértékű hosszabb távú viselkedésváltozással jár együtt [21]. Mivel a testsúlykontroll sokféle és sokrétű változtatást igényel, és számos lemondással jár, érdemes elismerni és méltányolni a páciens változásra irányuló erőfeszítéseit; megdicsérni az eredményeit; valamely viselkedésváltozás sikertelensége esetében pedig bátorítani és akár új cél kitűzésével vagy új megvalósítási mód felkutatásával megtámogatni a változás folyamatát. Az elhízással élők körében is gyakori az elhízással kapcsolatos negatív attitűd, és hajlamosak magukat is negatív színben látni, ezért fontos a címkézés kerülése, mert nemcsak rossz érzést kelt a páciensben, hanem valójában fel is menti az erőfeszítések megtétele alól [21]. Mindebben segíthet az esetleges kudarcok, megbotlások normalizálása; annak kifejezése, hogy a testsúlykontroll nehéz; illetve az indokolatlan gondolatok reálisabb gondolatokkal való helyettesítése (kognitív újrastrukturálás). Ha pedig a páciens csak részsiker(eke)t ér el valamely viselkedés(ek) megváltoztatása során, érdemes méltányolni az előrehaladást, és a páciens hibáztatása helyett inkább előremutató kérdéseket feltenni. Ha például a páciens a megbeszélt $500 \mathrm{kcal}$ energiakorlátozás helyett csak 300 kcal csökkenést tud felmutatni, akkor érdemes explicite megdicsérni a csökkentésért; rákérdezni, hogy hogy sikerült ezt megvalósítani; és megtudakolni, hogy vajon mi képezte az akadályát annak, hogy megvalósítsa a megbeszélt csökkentést a kalóriabevitelben, illetve mi segítene neki abban, hogy mégis sikerüljön ezt elérnie.

Hangsúlyozandó továbbá a szakember aktív segítsége a páciens motiválásában és az együttmúködés növelésében [21] a változás folyamatának valamennyi szakaszában. Ez az elem is több mindent foglal magában. Egyfelől jelenti a terápiás kezdeményezést, amelyben segíthet a motivációs interjú szemléletének elsajátítása, technikáinak ismerete és megfelelő alkalmazása [21, 24-26]. Az aktív segítség másfelől az aktív és megerősítő érdeklődést is jelenti a páciens és a változás folyamata iránt, valamint a törődés kifejezését, amely megnyilvánulhat a konzultációk során, de abban is, hogy a konzultáció lemondása vagy a páciens távolmaradása esetében a szakember felveszi vele a kapcsolatot, érdeklődve a páciens hogyléte és a terápia lemondásának indoka felől, szorgalmazva a konzultáció mielőbbi pótlását.

Mivel a változás hosszú folyamat, érdemes időről időre világos, egyértelmű visszajelzést nyújtani a páciensnek az aktuális helyzetéről, az előrehaladásáról és ennek következményeiről, illetve kockázatairól [21]. A visszajelzés forrása és formája egyaránt sokféle lehet. Az objektív visszajelzésre példa a vérnyomás- és pulzusmérés eredménye vagy a laboratóriumi lelet. További lehetőség az önmegfigyelési naplók áttekintése. A viselkedés szisztematikus önmegfigyelése a viselkedésterápia egyik sarokköve, mert növeli a tudatosságot a különféle viselkedések tekintetében, és lelassítja a döntéshozatali folyamatokat, így a pácienseknek lehetôségük nyílik az egészségesebb választások megtételére. Az önmegfigyelési naplók ugyanakkor figyelmeztetnek a kihágásokra, és visszajelzést nyújtanak az előrehaladásról is [7-8]. Az önmegfigyelés a testsúlykontroll esetében kiemelt jelentőséggel bír, és a testtömegre, táplálékbevitelre és fizikai aktivitásra egyaránt vonatkozhat. A testtömeggrafikon vezetésének segítségével például nyomon követhető a súlyváltozás trendje, emellett a rendszeres mérés elősegíti, hogy a páciensek meglássák a kapcsolatot a viselkedésük és a testtömegük között [7]. Az étkezési napló segítségével nemcsak az étkezések mintázata és az elfogyasztott ételek/italok mennyisége és minősége ismerhető meg, hanem feltárulnak a súlycsökkenés akadályai is (például a rejtett szénhidrátbevitel forrásai, a maladaptív táplálkozási szokások), növekszik az evés tudatossága és (lévén minden elfogyasztott étel és ital rögzítésre kerül, ami szégyenérzést kelthet a páciensben) eleve csökken az energiabevitel. További példa a visszajelzésre az aggodalom kifejezése, akár a családtagokkal végzett heteroanamnézis során elhangzottak fényében, akár a szakember saját tapasztalatai, megérzései alapján. A különféle visszajelzések így a viselkedésváltozás optimalizálásának és fenntartásának segítőivé, támogatóivá és a motiváció növelésének eszközeivé is válhatnak.

A szakirodalmi adatok alapján úgy túnik, hogy az elhízás kezelésének legnagyobb kihívása nem a fogyás, hanem az elért fogyás hosszú távú megtartása [4]. A túlfogyasztásra kísértő és fizikai inaktivitásra csábító környezetben mind a cselekvés, mind pedig a fenntartás fázisában kiemelt figyelem szentelendő a megbotlás, illetve visszaesés szempontjából veszélyeztető tényezőknek. Az eseti megbotlások bizonyos helyzetekre (például ünnepi időszak) vagy akár felfokozott érzelmi állapotra vezethetők vissza. Szükséges ezekre figyelmet fordítani, azonban a katasztrofizálás, a reménytelenség érzése és a passzivitás kerülendő, mert megnövelheti a visszaesés valószínûségét. Érdemes a megbotlást úgy tekinteni, mint amely várható, időleges és sikeresen leküzdhető. Ugyanakkor érdemes elöre feltérképezni a magas kockázatú helyzeteket és felkészülni a megfelelő válaszokra a megbotlás megelőzése érdekében. Itt is többféle technika áll rendelkezésre, mint amilyen például a tervezés, a tudatos evés, a problémamegoldás, illetve a problematikus gondolatok átkeretezése. Ha a megelőzési kísérlet ellenére mégis megbotlás történt, az arra való mihamarabbi konstruktív reagálás után érdemes elmélkedni a hátterében álló ok(ok)on és a problémamegoldás stratégiáját alkalmazni a későbbi, hasonló helyzetek kezelésére. A korábbi evési mintázat és fizikai inaktivitás tartós visszatérésére (és ezáltal a visszahízásra) vonatkozóan magas 
kockázatúak lehetnek bizonyos életszakaszok (például szabadság, betegség, kényszerü mozgáskorlátozottság). Ezek esetében jól alkalmazhatók az előre kidolgozott "készenléti tervek", illetve a testsúlykontroll felfüggesztésére vonatkozó költség-haszon-elemzés lefolytatása [14].

A hosszú távú testsúlymegtartás (-fenntartás) szakasza megköveteli a súlycsökkenés során elsajátított ismeretek, készségek és stratégiák frissen tartását és folyamatos alkalmazását. A siker egyik legfontosabb prediktora a rendszeres testtömegmérés [34]. Ajánlott a heti egy mérés, a megtartani kívánt testtömeg alatt és felett $2 \mathrm{~kg}$-ot hagyva kijelölni a célsúlytartományt, és a heti mérések eredményét rögzítve figyelemmel kísérni a testtömeg alakulásának trendjét; a tartományból való bármely irányú kilépés esetében megtenni a szükséges intézkedéseket; illetve azonosítani és megoldani a súlyváltozás hátterében álló tényezőket [14]. Mivel a testtömeg megtartása jelentős erőfeszítéseket igényel, ugyanakkor kevésbé jutalmazó értékű, mint maga a fogyás [13], érdemes arra bátorítani a pácienst, hogy gondolja át élete fóbb területeit (egészség, lélek, társas kapcsolatok és munka), és gyưjtse össze, hogy milyen pozitív változásokat észlelt a súlycsökkenése következtében, azaz miért lenne érdemes megtartania az elért testtömegét. Mindez igen hasznos lesz majd akkor, amikor megrendül a testsúlymegtartásra vonatkozó elhatározása [14]. Tsai és Wadden [1] kezelésválasztási algoritmusában szerepel, hogy az 5-10\%-os súlycsökkenés elérése után a további fogyás szorgalmazása helyett az elért fogyás megtartása a cél, amit a páciensek személyre szabott testsúlymegtartási tervének kidolgozásával lehet támogatni. A súlymegtartási terv egyfelől hasznos összefoglalásul szolgál a testsúlykontrollt támogató készségeknek, másfelől pedig útmutatást ad a jövőre nézve. Főbb részei a következők [14]: 1) a megtartani kívánt súlytartomány; 2) a súlymegtartás személyes okai; 3 ) a súlymegtartást szolgáló folyamatok (úgymint: rendszeres testtömegmérés; a táplálkozásra és a fizikai aktivitásra vonatkozó magatartási szabályok [8, 14, 29]; valamint a testsúlymegtartást segítő gondolkodásmód elemei, mint például tervezés, kognitív újrastrukturálás, pozitív énállítások); és 4) a visszahízást megelőző folyamatok. Ez utóbbiba a következők tartoznak: a visszahízás korai jeleinek azonosítása (a testtömeggrafikon alapján); ennek az energiamérleg szempontjából történő értelmezése (például a korábbihoz képest fokozott energiabevitel és csökkent -leadás); az ezek hátterében álló okok (például események, érzések) azonosítása; a testtömeg korrekcióját és a célsúlytartományba való visszatérését szolgáló magatartások bevezetése (például kalóriakorlátozás); és végül a súlygyarapodás hátterében álló probléma megoldása [14]. Mindez elösegíti, hogy a páciens a megfelelő éberséggel viseltessen a testtömege alakulása iránt, valamint gyorsan és hatékonyan tudjon reagálni a visszahízás veszélyére. Ez azért különösen jelentős, mert ekkor még viszonylag kis változtatásokkal és mérsékelt erőfeszítéssel orvosolhatók a problémák.
Nagyobb mértékű visszahízás esetében gyakorta megjelenik a szégyen, a büntudat és a tehetetlenség érzése, leértékelődik az elért siker jelentősége, ami a testsúlykontroll teljes feladásához vezethet, visszahízást okozva annak minden hozadékával az egyén testi és lelki egészségére nézve.

\section{Következtetés}

Az elhízás nagy népegészségügyi jelentőségü, önmagában is krónikus betegségként értelmezendő, a megbetegedés, az idő előtti elhalálozás kockázatát fokozó, az életminőséget pedig jelentősen rontó állapot. Hazánkban a felnőtt lakosság mintegy kétharmada bír kisebbnagyobb súlytöbblettel, éppen ezért a súlyfelesleggel élők igen nagy gyakorisággal jelenhetnek meg az egészségügyi ellátórendszer bármely szektorában. Noha többféle professzionális súlycsökkentő kezelés érhető el, sokan nem kérnek segítséget és támogatást szakemberektől. Ennek hátterében számos ok feltételezhető, mint amilyen például az elhízás negatív társadalmi megítélése; a szakemberek vonakodása attól, hogy kéretlenül a testsúlykontrollt támogató tanácsokat adjanak; vagy a páciens változásra való készenlétének hiánya, esetleg tehetetlenségérzése a testsúlykontroll kapcsán.

Mivel azonban az elhízás számos krónikus betegség kockázati tényezője, hasznos lenne, ha nemcsak a súlycsökkentő kezelésre specializálódott szakemberek, hanem az alapellátásban dolgozók minél szélesebb köre tudna hatékony segítséget nyújtani a testsúlykontroll támogatásában. Ennek előfeltétele az elhízással kapcsolatos saját attitűdök feltárása és szükség esetében formálása; a viselkedésváltozás természetének és szakaszainak ismerete; a motiváló stratégiák; valamint az elhízás bizonyítékalapú kognitív viselkedésterápiás kezelése számos stratégiájának ismerete és megfelelő alkalmazása.

A viselkedésváltozás transzteoretikus modellje (TTM) [17-19] révén lehetôség nyílik elméleti alapon kidolgozott és levezetett, egyénre szabott intervenciót nyújtani teljes populációkra, beleértve a változásra nem motivált egyéneket is. A TTM vonzó megközelítés, mert segít azonosítani azokat az intervenciótípusokat, amelyek a leghatékonyabbak lehetnek a változás egyes stádiumaiban (úgymint fontolgatás előtti fázis, a fontolgatás fázisa, felkészülés, cselekvés, illetve fenntartás). A modell ideális alkalmazása, ha elsőként felmérjük a kliens stádiumát a változás folyamatában, majd lefolytatjuk az intervenciók jól meghatározott sorozatát, átsegítve a személyt a különböző fázisokon [22].

Időbeli korlátozottság (például családorvosi, diabetológiai, dietetikusi konzultáció) esetében hatékony megközelítés lehet a testsúlykontrollt szolgáló egészségmagatartások elsajátításának és a kedvezőtlen szokások megváltoztatásának elősegítésére az ún. minimális intervenció alkalmazása, amely a komponensei angol elnevezése (úgymint Ask, Advise, Assess, Assist, Arrange) alapján „5A” módszer néven is ismert $[16,35]$. Az eredetileg 
a dohányzásról való leszokás támogatására kidolgozott intervenció elhízásra adaptált változatának esetében a tudakozódás (ask) arra vonatkozik, hogy a szakember engedélyt kér a pácienstől a testtömegről való beszélgetés lefolytatásához, és ítélkezésmentes módon felméri a páciens változásra való készenlétét. A tájékozódás (assess) keretében megméri a testtömeget, testmagasságot, derékkörfogatot, kiszámítja a BMI-t, meghatározza a súlyfelesleg mértékét, továbbá feltárja annak okait és szövődményeit. A tanács (advise) megfogalmazása során a szakember tájékoztatja a pácienst a súlyfelesleg egészségi kockázatairól, a mérsékelt súlycsökkenés előnyeiről, a hosszú távú testsúlykontroll szükségességéról és a kezelési lehetőségekről. A páciens viselkedésváltoztatással kapcsolatos érdeklődése és hajlandósága alapján, vele együttmúködve kerülnek kiválasztásra a megfelelő kezelési célok és módszerek. A közös döntéshozatal növeli a páciens bevonódását a viselkedés megváltoztatásába, és reálisabb célkitűzést eredményez. A választási lehetőségek felmutatása elősegíti az ellenállás leépítését, a meleg, empatikus, nem ítélkező stílus pedig nagyobb együttmüködést vált ki. A szakember a támogatás (assist) során különböző viselkedéses technikák alkalmazásával segíti, hogy a páciens azonosítsa és legyőzze a nehézségeket, akadályokat, illetve elérje az együttesen meghatározott célokat. Idetartozik például a páciens motivációjának növelése, problémamegoldási és megküzdési készségeinek fejlesztése; továbbá a modellálás, a viselkedés gyakorlása és a (z ön)jutalmazás. E technikák elősegítik, hogy a páciens megszerezze a viselkedésváltozáshoz szükséges készségeket, önbizalmat és társas, illetve környezeti támogatást. Ha szükséges, kiegészítésként gyógyszeres kezelés is alkalmazható, valamint megszervezhető a megfelelő specialista bevonása a kezelésbe. Végül a tevékenység ellenőrzése (arrange) a páciens nyomon követését jelenti. A rendszeres (személyesen vagy akár telefonon történő) konzultációval folyamatos segítséget, támogatást lehet nyújtani a páciens számára, valamint az erőfeszítések és tapasztalatok tükrében szükség esetén módosítani lehet a kezelési tervet (például intenzívebb vagy speciális kezelés választása) [36-38].

Összefoglalóan elmondható, hogy a kezelés során a hangsúly a klinikailag jelentős, 5-10\%-os súlycsökkenés elérésének és hosszú távú megtartásának támogatásán van. A jelen tanulmány ebben kívánt segítséget nyújtani a szakemberek számára.

Anyagi támogatás: A közlemény megírása anyagi támogatásban nem részerült.

A szerző a cikk végleges változatát elolvasta és jóváhagyta.

Érdekeltségek: A szerző alkalmanként maga is tart Williams ÉletKészségek ${ }^{\circledR}$ Stresszkezelő és Pszichoszociális Készségfejlesztő Tréninget, önköltséges formában.

\section{Irodalom}

[1] Tsai AG, Wadden TA. Treatment of obesity in primary care. In: Wadden TA, Bray GA. (eds.) Handbook of obesity treatment (2. edn.). The Guilford Press, New York, London, 2018; pp. $453-465$.

[2] Németh Á. Nutritional status, body image and body weight control. In: Németh Á, Költő A. (eds.) Health Behaviour in Schoolaged Children (HBSC): A WHO-collaborative cross-national study, National Report 2014. [Tápláltsági állapot, testkép és testtömeg-szabályozás. In: Németh Á, Költő A. (szerk.) Egészség és egészségmagatartás iskoláskorban 2014. Az iskoláskorú gyermekek egészségmagatartása elnevezésü, az Egészségügyi Világszervezettel együttmúködésben megvalósuló nemzetközi kutatás 2014. évi felméréséról készült nemzeti jelentés.] Nemzeti Egészségfejlesztési Intézet, Budapest, 2016; pp. 160-171. [Hungarian]

[3] Rurik I, Ungvári T, Szidor J, et al. Obese Hungary. Trend and prevalence of overweight and obesity in Hungary, 2015. [Elhízó Magyarország. A túlsúly és az elhízás trendje és prevalenciája Magyarországon, 2015.] Orv Hetil. 2016; 157: 1248-1255. [Hungarian]

[4] Wadden TA, Bray GA. (eds.) Handbook of obesity treatment (2. edn.). The Guilford Press, New York, London, 2018.

[5] Lukács L. Crisis in dieting. [A diéta mint krízis.] Mentálhig Pszichoszomat. 2017; 18: 105-124. [Hungarian]

[6] Dalle Grave R, Centis E, Marzocchi R, et al. Major factors for facilitating change in behavioral strategies to reduce obesity. Psychol Res Behav Manag. 2013; 6: 101-110.

[7] Gomez-Rubalcava S, Stabbert K, Phelan S. Behavioral treatment of obesity. In: Wadden TA, Bray GA. (eds.) Handbook of obesity treatment (2. edn.). The Guilford Press, New York, London, 2018; pp. 336-348.

[8] Kelley CP, Sbrocco G, Sbrocco T. Behavioral modification for the management of obesity. Prim Care 2016; 43: 159-175.

[9] Pearson D, Grace C. Weight management. A practicioner's guide. Wiley-Blackwell, Chichester, 2012.

[10] Puhl RM, Heuer CA. Obesity stigma: important considerations for public health. Am J Public Health 2010; 100: 1019-1028.

[11] Fruh SM, Nadglowski J, Hall HR, et al. Obesity stigma and bias. J Nurse Pract. 2016; 12: 425-432.

[12] Weight bias and obesity stigma: Considerations for the WHO European Region. WHO, Copenhagen, 2017. Available from: http://www.euro.who.int/__data/assets/pdf_file/0017/ 351026/WeightBias.pdf [accessed: May 11, 2018].

[13] Cooper Z, Fairburn CG, Hawker DM. Cognitive-behavioral treatment of obesity. A clinician's guide. Guilford Press, New York, London, 2004

[14] Dalle Grave R, Sartirana M, El Ghoch M, et al. Treating obesity with personalized cognitive behavioral therapy. Springer, Cham, 2018.

[15] Puhl R, Peterson JL, Luedicke J. Motivating or stigmatizing? Public perceptions of weight-related language used by health providers. Int J Obes (Lond). 2013; 37: 612-619.

[16] Urbán R. Basics of health psychology. [Az egészségpszichológia alapjai.] ELTE Eötvös Kiadó, Budapest, 2017. [Hungarian]

[17] Prochaska JO, DiClemente CC, Norcross JC. In search of how people change: applications to addictive behaviors. Am Psychol. 1992; 47: 1102-1114.

[18] Prochaska JO, Norcross JC, DiClemente CC. Changing for good. A revolutionary six-stage program for overcoming bad habits and moving your life positively forward. [Valódi újrakezdés. Hatlépcsős program ártalmas szokásaink leküzdésére és életünk jobbá tételére.] Ursus Libris, Budapest, 2009. [Hungarian]

[19] Prochaska JO, Prochaska JM. Behavior change. In: Nash DB, Reifsnyder J, Fabius RJ, et al. (eds.) Population health: Creating 
a culture of wellness. Jones and Bartlett, Sudbury, 2011; pp. 23-41.

[20] Czeglédi E. The application of the transtheoretical model of behavior change for the treatment of obesity. [A viselkedésváltozás transzteoretikus modelljének alkalmazási lehetőségei az elhízás kezelésében.] Mentálhig Pszichoszomat. 2012; 13: 411-434. [Hungarian]

[21] Miller WR, Rollnick S. Motivational interviewing. Preparing people to change addictive behavior. Guilford Press, New York, London, 1991.

[22] Kristal AR, Glanz K, Curry SJ, et al. How can stages of change be best used in dietary interventions? J Am Diet Assoc. 1999; 99: 679-684.

[23] Túry F, Czeglédi E. Psychosomatics of obesity and possibilities of psychotherapy. In: Bedros JR. (ed.) Clinical obesitology. [Az elhízás pszichoszomatikája és pszichoterápiás lehetőségei. In: Bedros JR. (szerk.) Klinikai obezitológia. Semmelweis Kiadó, Budapest, 2017; pp. 181-200. [Hungarian]

[24] Urbán R. Motivational interviewing. In: Demetrovics Zs. (ed.) Basics of addictology III. The principles of treating addictions. [A motivációs interjú. In: Demetrovics Zs. (szerk.) Az addiktológia alapjai III. Az addikciók terápiájának alapkérdései.] ELTE Eötvös Kiadó, Budapest, 2009; pp. 277-293. [Hungarian]

[25] Arnaout B, Levounis P, Marienfeld C. Motivational interviewing for clinical practice. [Motivációs interjú a klinikai gyakorlatban.] Oriold és Társai Kft., Budapest, 2018.

[26] Pócs D, Hamvai C, Kelemen O. Health behavior change: motivational interviewing. [Magatartás-változtatás az egészségügyben: a motivációs interjú.] Orv Hetil. 2017; 158: 1331-1337. [Hungarian]

[27] Teixeira PJ, Silva MN, Mata J, et al. Motivation, self-determination, and long-term weight control. Int J Behav Nutr Phys Act. 2012; 9: 22. Available from: https://www.ncbi.nlm.nih.gov/ pmc/articles/PMC3312817/ [accessed: January 21, 2019].

[28] Bedros JR. (ed.) Clinical obesitology. [Klinikai obezitológia.] Semmelweis Kiadó, Budapest, 2017. [Hungarian]

[29] Perczel-Forintos D. Cognitive behavioral therapies for obesity treatment. In: Perczel-Forintos D, Mórotz K. (eds.) Cognitive behavioral therapy. 4 th revised and extended edition. [Kognitív viselkedésterápiás lehetôségek az elhízás kezelésében. In: Perczel-Forintos D, Mórotz K. (szerk.) Kognitív viselkedéste- rápia. 4. átdolgozott és bővített kiadás.] Medicina Könyvkiadó, Budapest, 2019; pp. 531-549. [Hungarian]

[30] Ries AV, Blackman LT, Page RA, et al. Goal setting for health behavior change: evidence from an obesity intervention for rural low-income women. Rural Remote Health 2014; 14: 2682. Available from: https://www.rrh.org.au/journal/article/2682 [accessed: May 20, 2019].

[31] Varkevisser RD, van Stralen MM, Kroeze W, et al. Determinants of weight loss maintenance: a systematic review. Obes Rev. 2019; 20: 171-211.

[32] Perczel-Forintos D. Awareness and self-reflection: mindfulness interventions in the treatment of obesity. [Tudatosság és önreflexió: a mindfulness módszerek szerepe az elhízás kezelésében.] Mentálhig Pszichoszomat. 2017; 18: 125-148. [Hungarian]

[33] Stauder A, Balog P, Kovács M, et al. The Hungarian adaptation of the Williams LifeSkills ${ }^{\circledast}$ stress management and psychosocial skills training program and ten years' implementation in Hungary. [A Williams ÉletKészségek ${ }^{\circledR}$ stresszkezelő és pszichoszociális készségfejlesztő program magyar adaptációja és 10 éves tapasztalatai.] Mentálhig Pszichoszomat. 2016; 17: 81-95. [Hungarian]

[34] Burke LE, Wang J, Sevick MA. Self-monitoring in weight loss: a systematic review of the literature. J Am Diet Assoc. 2011; 111 : 92-102.

[35] Pilling J. Medical communication in practice. 2nd edition. [Orvosi kommunikáció a gyakorlatban. 2. kiadás.] Medicina Könyvkiadó, Budapest, 2018. [Hungarian]

[36] Vallis M, Piccinini-Vallis H, Sharma AM, et al. Modified 5 As: minimal intervention for obesity counseling in primary care. Can Fam Physician 2013; 59: 27-31.

[37] Whitlock EP, Orleans CT, Pender N, et al. Evaluating primary care behavioral counseling interventions: an evidence-based approach. Am J Prev Med. 2002; 22: 267-284.

[38] Ainsworth BE, Youmans CP. Tools for physical activity counseling in medical practice. Obes Res. 2002; 10: 69S-75S.

(Czeglédi Edit dr., Budapest, Nagyvárad tér 4., 1089 e-mail: czedit@gmail.com)

\section{"Suum quique placet." (A sajátja mindenkinek tetszik.)}

A cikk a Creative Commons Attribution 4.0 International License (https://creativecommons.org/licenses/by/4.0/) feltételei szerint publikált Open Access közlemény,

melynek szellemében a cikk bármilyen médiumban szabadon felhasználható, megosztható és újraközölhető, feltéve, hogy az eredeti szerző és a közlés helye, illetve a CC License linkje és az esetlegesen végrehajtott módosítások feltüntetésre kerülnek. (SID_1) 